\title{
Peran Indonesia di G-20: Peluang dan Tantangan
}

\author{
Cindy Larasasati \& Ester Desy Natasya \\ UPN Veteran Jakarta
}

\begin{abstract}
Abstrak
Sejak terpilih sebagai Presiden Indonesia pada tahun 2014, Joko Widodo telah menetapkan empat prioritas kebijakan luar negeri, yakni 1) mempromosikan identitas Indonesia sebagai negara kepulauan; 2) meningkatkan peran global dalam diplomasi middle power; 3) mempererat kerja sama di area Asia-Pasifik; dan 4) reformasi lebih lanjut di kementrerian luar negeri untuk menekankan pada diplomasi ekonomi. Prioritas kedua sangat menarik karena menyebutkan peran global Indonesia sebagai kekuatan menengah. Salah satunya dengan mendorong peran aktif Indonesia di G-20. Mandat utama G-20 adalah untuk mencegah krisis keuangan internasional di masa depan. Ini berusaha membentuk agenda ekonomi global. Peningkatan peran dalam forum G-20 memang bukanlah hal yang mudah, tapi penulis akan menjelaskan beberapa peluang dan tantangan dalam keanggotaan Indonesia di G-20. Penulis akan menggunakan perspektif liberal untuk menganalisis kontribusi Indonesia di G-20. Melalui perspektif tersebut, penulis akan melakukan analisis yang terbagi ke dalam dua bagian utama. Bagian pertama akan berfokus pada kerangka kerja sama G-20 secara umum. Sedangkan pada bagian kedua, penulis akan menguraikan kerangka teoretis dan upaya peningkatan peran Indonesia di G-20.
\end{abstract}

Kata kunci: kebijakan luar negeri, G-20, peluang dan tantangan, diplomasi, Indonesia

Since he was elected as the President of Indonesia in 2014, Joko Widodo had set four foreign policy priorities, here are the points; 1) promoting Indonesia's identity as an archipelagic state, 2) enhancing the global role of middle power diplomacy 3) expanding engagement in the Asia-Pacific region, and 4) further reform of the foreign ministry to emphasize economic diplomacy. Second priority is interesting as it states enchanging Indonesia's global role of middle power diplomacy. We argue that in order to realize the second priority, Indonesia can play an active role in G-20. G-20's primary mandate is to prevent future international financial crises and seeks to shape global economic agenda. We realize that attempting to enhance Indonesia's position to play a more important role in G-20 is not that easy, but we will explain some opportunities and some challenges in G-20. We will use liberal perspective to analyze the contribution of Indonesia in G-20, and break it down to a few sections in the paper. The first section is Introduction which talks about G-20 in general, while the second section elaborates on the theoretical framework. Finally, the last section includes conclusion and solution regarding the role of Indonesia in G-20.

Keywords: foreign policy, G-20, opportunity and challenge, diplomacy, Indonesia 
Indonesia melantik presiden barunya, Joko Widodo, atau yang lebih dikenal dengan panggilan "Jokowi" pada Oktober 2014. Jokowi berjanji akan membangun pemerintah yang lebih efektif dan lebih transparan. Politik luar negeri Jokowi lebih menunjukan arah politik luar negeri yang lebih bersifat low profile dan lebih fokus ke urusan dalam negeri. Ada 4 prioritas kebijakan politik luar negeri Jokowi seperti 1) mempromosikan identitas Indonesia sebagai negara kepulauan; 2) meningkatkan peran global diplomasi middle power; 3) memperluas perjanjian di wilayah Indo-Pasifik; dan 4) reformasi lebih lanjut kementerian luar negeri untuk menekankan diplomasi ekonomi (www.presidenri.go.id, 2016).

Prinsip politik luar negeri yang dianut oleh Jokowi tetaplah berlandaskan pada prinsip bebas-aktif. Visi ini menunjukan makna dari "kebebasan" Indonesia dengan cara mewujudkan kedaulatan, kemandirian, dan kepribadian nasional. Jokowi yang ingin menunjukan sifat dan sikap 'aktif' untuk merealisasikan kemandirian nasional atas kerja sama positif dan konstruktif yakni gotong royong. Sebagai negara kepulauan, kompetensi maritim penting bagi Indonesia, sehingga Jokowi menegaskan tujuannya untuk membangun Indonesia sebagai "Poros Maritim Dunia". Di tahun 2015 Jokowi juga ingin mengedepankan ekonomi Indonesia, adanya ASEAN Economic Community (AEC), yang bermaksud untuk menciptakan satu pasar di antara sepuluh negara anggota ASEAN, telah diimplementasikan pada akhir tahun 2015.

Prioritas lainnya yang ingin di kedepankan Jokowi adalah meningkatkan peran Indonesia sebagai negara middle power di dunia. Dalam butir pertama Nawacita Jokowi, disebutkan pula bahwa "Kami akan memperkuat peran Indonesia dalam kerja sama global dan regional untuk membangun saling pengertian antar peradaban, memajukan demokrasi dan perdamaian dunia, meningkatkan kerja sama pembangunan Selatan-Selatan, dan mengatasi masalahmasalah global yang mengancam umat manusia." (www.presidenri. go.id, 2016). Meningkatkan peran Indonesia bisa dilihat dari keikutsertaan Indonesia dalam forum G-20. Presiden Jokowi melihat G-20 sebagai peluang bagi Indonesia. Dia mengedepankan strategi politik luar negeri yang bebas-aktif berdasarkan kepentingan nasional dan pada saat yang sama memperkuat peran Indonesia dalam konteks kerja sama global di dalam forum G-20. Sebagaimana disampaikan dalam pidatonya, Presiden Jokowi berharap agar 
negara-negara G-20 dapat memberikan asistensi untuk mengurangi kesenjangan digital antara negara maju dan berkembang serta meningkatkan kerja sama dalam pengembangan teknologi antara negara-negara anggota G-20.

Arah pemerintahan Presiden Joko Widodo, Indonesia memiliki alasan yanglebih signifikanuntukmengintensifkan keikutsertaannya di forum kerjasama ekonomi internasional. Presiden Joko Widodo memang pemimpin yang pragmatis dan sangat selektif terkait pertemuan-pertemuan forum internasional yang hendak dihadiri. Akan tetapi, Joko Widodo menaruh perhatian yang cukup intens terhadap G-20. Menurut Joko Widodo, kehadirannya di KTT G-20 sangat penting untuk mendapatkan manfaat nyata bagi Indonesia, terutama untuk mendukung pembangunan nasional. Jokowi sering menunjuk wakil presiden untuk mewakili Indonesia di KTT lain yang dianggap mampu memberikan hasil namun kurang signifikan. KTT G-20 dan Asosiasi Bangsa-Bangsa Asia Tenggara (ASEAN) telah masuk dalam daftar prioritas utama Indonesia. Hal ini mencerminkan perspektif pemikiran ke depan mengenai kesadaran akan pentingnya ASEAN dan G-20 sebagai platform strategis dalam rangka pencapaian visi nasional di bawah rezim Jokowi.

Alasan mengapa penulis memilih untuk membuat paper ini antara lain adalah karena penulis merasa tertantang untuk mengetahui seberapa jauh peran Indonesia dalam upaya berkontribusi di forum G-20. Tak hanya melihat seberapa jauh kontribusi Indonesia, tetapi juga seberapa penting posisi indonesia dalam memainkan perannya sebagai anggota G-20. Selain itu, penulis juga akan membahas dan menganalisis peluang dan tantangan yang didapatkan dalam forum G-20 ini. Tak hanya itu, kami juga akan mendiskusikan upaya Presiden Jokowi dalam menguatkan peran Indonesia di dalam G-20. Tantangan tidak hanya muncul dari luar Indonesia (eksternal), tetapi juga tantangan yang muncul secara internal.

\section{Sejarah dan Latar Belakang Pembentukan G-20}

Sejak tahun 1986, pengelompokan menteri keuangan dalam Group of Seven (G-7) telah terbukti cukup penting dalam fungsinya sebagai forum diskusi informal dan substantif mengenai isuisu ekonomi internasional. Salah satu tujuan dari forum tersebut 
adalah pencapaian suatu pemahaman dan koordinasi yang lebih erat di antara para pembuat kebijakan di negara-negara G-7. Namun, kurangnya representasi pasar dalam G-7 membatasi kemampuan forum ini untuk menangani beberapa masalah terkait perkembangan ekonomi internasional dan sistem keuangan (Kirton, 1999). Sebagai hasilnya, G-7 dianggap kurang efektif dan tidak sesuai dengan harapan negara-negara penciptanya sehingga pada tanggal 25 September 1999, di Washington, D.C., para menteri keuangan dari kelompok industri terkemuka Group of Seven (G-7) mengumumkan pembentukan Group of Twenty (G-20). Tujuan dasar dari dibentuknya G-20 untuk berdiskusi, mempelajari, meninjau kembali isu-isu kebijakan di antara negaranegara industri dan pasar negara berkembang dengan tujuan untuk mempromosikan stabilitas keuangan internasional. Anggota G-20 terdiri dari Argentina, Australia, Brazil, Canada, China, France, Germany, India, Indonesia, Italy, Japan, Mexico, Russia, Saudi Arabia, South Africa, South Korea, Turkey, Inggris, Amerika Serikat dan Uni Eropa. Keanggotaan G-20 yang terdiri dari negara maju dan negara berkembang terbesar di dunia, mewakili sekitar dua pertiga populasi dunia, 85 persen produk domestik bruto dan lebih dari 75 persen perdagangan global (Kirton, 1999).

Para pemimpin G-20 bertemu setiap tahun dan setiap presiden dari G-20 mengundang beberapa tamu negara setiap tahunnya. Selain itu, Menteri Keuangan dan Gubernur Bank Sentral bertemu secara teratur sepanjang tahun untuk membahas cara-cara untuk memperkuat ekonomi global, mereformasi lembaga keuangan internasional, memperbaiki peraturan keuangan dan menerapkan reformasi ekonomi utama yang dibutuhkan dalam setiap ekonomi anggota. Mendasari pertemuan ini adalah program pertemuan sepanjang tahun di antara pejabat senior dan kelompok kerja yang mengkoordinasikan kebijakan mengenai isu-isu spesifik (Kirton, 1999).

Melalui partisipasi luas oleh negara-negara industri dan pasar negara berkembang utama, G-20 akan mewakili berbagai sudut pandang. G-20 merupakan model tepat untuk kerja sama di dunia sekarang ini. Kerja sama yang memberi tanggapan terhadap krisis keuangan global sebagai bukti dampak dari kerja sama G-20. G-20 memperkenalkan triliunan dolar dalam paket stimulus fiskal di seluruh dunia, yang menyelamatkan atau menciptakan 
jutaan lapangan kerja yang seharusnya dihancurkan. Hal ini juga menempatkan langkah-langkah untuk mengurangi jatuhnya pasar keuangan dan membantu menjaga kepercayaan konsumen dan bisnis.

\section{Manfaat G-20 bagi Indonesia dan Peningkatan Peran Aktif Indonesia di G-20}

Indonesia telah menjadi anggota G-20 sejak forum intergovernmental ini dibentuk di tahun 1999. Bagi Indonesia klub eksklusif ini merupakan arena bergengsi tinggi tempat Indonesia dapat berkontestasi dalam berbagai upaya pencapaian kepentingan nasionalnya. Dibawah pemerintahan Jokowi, Indonesia punya komitmen untuk meningkatkan pengaruh Indonesia dalam kerja sama internasional. Karena G-20 banyak memberikan manfaat bagi ekonomi internasional, maka hal tersebut bisa menjadi peluang serta potensi keuntungan yang cukup strategis bagi pencapaian kepentingan ekonomi Indonesia di level internasional.

Keikutsertaan Indonesia pada G-20 juga dimanfaatkan oleh Jokowi untuk berbagi pengalaman dalam mengelola transformasi digital. Ini sejalan dengan usaha pemerintah dalam rangka meningkatkan pendapatan masyarakat yang pada gilirannya akan mempersempit disparitas ekonomi, mendorong pemerataan, meningkatkan literasi digital dan mengakselarasi usaha mikro, kecil, dan menengah (UMKM).

Di bawah administrasi Joko Widodo, Indonesia telah mengadopsi blueprints sebagai rujukan utama delegasi Indonesia untuk berpartisipasi dalam berbagai tingkatan pada pertemuan G-20. Blueprints ini mewujudkan kepentingan, sasaran, dan prioritas nasional Indonesia untuk G-20. Ini menyoroti strategi untuk melaksanakan mandat konstitusi, yaitu untuk berkontribusi pada pembentukan tatanan global yang adil. Blueprints tersebut juga menginformasikan strategi di mana Indonesia harus menerapkan komitmennya terhadap G-20 di tingkat nasional.

Kerja sama yang memberi tanggapan terhadap krisis keuangan global sebagai bukti dampak dari kerja sama G-20. G-20 memperkenalkan triliunan dolar dalam paket stimulus fiskal di seluruh dunia yang menyelamatkan dan/atau menciptakan jutaan lapangan kerja yang 
seharusnya dihancurkan. Forum ini juga merumuskan langkahlangkah untuk mengurangi dampak jatuhnya pasar keuangan global dan membantu menjaga kepercayaan konsumen dan bisnis. G-20 sebagai komite krisis memiliki tanggung jawab utama untuk menangani krisis jangka pendek dan membangun struktur global yang tahan terhadap krisis di masa mendatang, baik jangka menengah maupun jangka panjang. Di dalam penanganan krisis, Indonesia dapat mengambil keuntungan dengan melihat dari mana akar krisis tersebut dan melakukan pembenahan di seluruh Indonesia. Selain itu, Indonesia juga dapat memanfaatkan posisinya dalam G-20 menangani krisis nasionalnya.

DalamG-20 Indonesiajuga dapatmeningkatkan investasi dan strategi investasi. Di KTT G-20, Hamburg, Jerman, misalnya Indonesia juga terlibat dalam beberapa pertemuan bilateral, diantaranya dengan Norwegia. Nilai perdagangan dan investasi yang tumbuh positif di tahun 2016 digunakan Jokowi sebagai momentum peningkatan kerja sama antara Indonesia dan Norwegia di masa yang akan datang. Nilai perdagangan 2016 mengalami peningkatan 40,5 persen dibanding tahun 2015. Sementara investasi mengalami peningkatan sebesar 772 persen, termasuk peningkatan investasi portofolio dari Pension Global Fund Norwegia. Perkembangan positif ini perlu terus kita pertahankan, atau bahkan ditingkatkan," kata Presiden Jokowi seperti dilansir drai siaran pers Biro Pers Sekretariat Presiden (Deutsche Welle, 2017).

Bagi Joko Widodo, G-20 memiliki kepentingan strategis tersendiri. Forum ini telah memprioritaskan perdagangan, investasi, dan infrastruktur dalam agenda, yang selaras dan sejalan dengan tujuan Jokowi untuk mencatatkan angka pertumbuhan ekonomi sebesar 7 persen di Indonesia (OECD, 2016). Perspektif G-20 tentang pentingnya infrastruktur untuk pertumbuhan ekonomi memberi pemerintahan Jokowi justifikasi kuat untuk mempercepat pembangunan infrastruktur nasional sebagai bagian dari agenda domestik. G-20 sendiri merupakan sarana strategis bagi Indonesia untuk mengekstrapolasi kepentingan nasional melalui diplomasi ekonomi, serta menampilkan berbagai capaian domestik yang selama ini ada. Bagi Jokowi yang lebih memfokuskan pemerintahannya pada isu-isu domestik, keanggotaan G-20 dapat memberikan kontribusi dan saran yang cukup signifikan dalam pembenahan ekonomi domestik. Selain itu, G-20 dapat mendorong optimalisasi 
pendapatan negara dan memperkuat postur anggaran pemerintah.

Keanggotaan pada G-20 telah menempatkan Indonesia sebagai salah satu pemain kunci dalam perekonomian global dan ikut menentukan kerangka kebijakan perekonomian di dunia ini. Penilaian itu didasarkan kepada indikator bahwa sebagai satu-satunya negara ASEAN di G-20, Indonesia dapat memperkuat posisinya sebagai salah satu motor ASEAN dan berperan sebagai penyampai suara dan kepentingan kolektif negara-negara ASEAN lainnya. Banyak manfaatyang dapat didapatkan Indonesia melaluikeanggotaannya di G-20. Pertama, Indonesia dapat mempercepat proses pembangunan nasionalnya seperti pembangunan infrastruktur, keuangan inklusif, mobilisasi sumber daya domestik, ketahanan pangan dan gizi, pengembangan sumber daya manusia, dan bisnis inklusif. Kedua, Indonesia dapat meningkatkan pencapaian ekonomi melalui sektor investasi dan perdagangan, dengan cara meningkatkan nilai ekspor melalui kerja sama dalam G-20, mendorong kontribusi investasi dan perdagangan di dalam pertumbuhan global, memanfaatkan jaringan global, melakukan evaluasi terhadap pelaksanaan perdagangan bebas, dan melakukan penguatan terhadap sistem perdagangan multilateral. Ketiga, dalam bidang ketenagakerjaan, Indonesia dapat melakukan pengawasan terhadap penyerapan tenaga kerja, mendorong angkatan kerja muda untuk bersikap lebih aktif, dan membantu keahlian dan ketenagakerjaan yang lebih berkualitas. Semua hal tersebut merupakan peluang yang dapat diperoleh Indonesia melalui kerja sama dan keanggotaan di G-20. Selain itu, keikutsertaan Indonesia pada G-20 juga dimanfaatkan oleh Jokowi untuk berbagi pengalaman dalam mengelola transformasi digital. Hal ini sejalan dengan usaha pemerintah dalam rangka meningkatkan pendapatan masyarakat yang pada gilirannya akan mempersempit disparitas ekonomi, mendorong pemerataan, meningkatkan literasi digital, dan mengakselarasi usaha mikro, kecil dan menengah (UMKM).

Salah satu agenda penting G-20 yang menarik perhatian Presiden Joko Widodo adalah pembangunan infrastruktur. Isu infrastruktur ini merupakan salah satu perhatian utama bagi kelompok Kerja Pembangunan pada tahun 2010. Sebagai konsekuensinya, hal tersebut mendapat dukungan serius dari jalur keuangan. Argumen untuk menempatkan 'infrastruktur' di bagian atas daftar prioritas cukup jelas: kurangnya infrastruktur adalah salah satu hambatan 
paling signifikan terhadap pertumbuhan inklusif, berkelanjutan, dan tangguh di negara-negara berkembang, dan khususnya di negara-negara berpenghasilan rendah (LICs). Pembangunan infrastruktur dipandang sebagai tindakan nyata untuk membuat "perbedaan nyata dan signifikan dalam kehidupan masyarakat". Oleh karena itu, Jokowi menempatkan pembenahan serta pembangunan infrastruktur sebagai salah satu sektor utama yang harus diperhatikan dalam kerangka kerja sama multilateral dengan negara-negara anggota G-20.

Investasi di bidang infrastruktur sangat penting dalam mengatasi hambatan pertumbuhan ekonomi, pengurangan kemiskinan, dan penciptaanlapangankerja.PresidenJokoWidodomenyambutagenda infrastruktur G-20 dengan sangat antusias, karena pembangunan infrastruktursepenuhnyasesuaidengan prioritasutama perencanaan pembangunan nasionalnya. Agenda ini dinyatakan dengan jelas dalam Rencana Pembangunan Jangka Menengah Nasional 20152019 (RPJMN 2015-2019) yang mencantumkan rencana ambisius untuk mengembangkan infrastruktur nasional, termasuk total 2.650 $\mathrm{km}$ jalan nasional baru, total $1.000 \mathrm{~km}$ jalan tol, generator listrik 35.000 Mega Watt, 15 bandara baru, dan total $3.258 \mathrm{~km}$ kereta api (RPJMN 2015-2019). Meski terlihat ambisius, namun proyek tersebut menjadi sebuah bukti nyata keseriusan pemerintahan Jokowi dalam melaksanakan pembangunan infrastruktur guna menyokong kesejahteraan masyarakat Indonesia.

Segera setelah pelantikannya sebagai Presiden pada bulan Oktober 2016, Joko Widodo memperkenalkan sebuah kebijakan untuk mempercepat laju pembangunan infrastruktur masif dan didukung oleh semua kementerian terkait. Demi mencapai tujuan ambisius ini, Presiden membentuk badan prioritas infrastruktur baru, Komite Percepatan Pembangunan Infrastruktur Prioritas (KPPIP) untuk meningkatkan investasi dan pertumbuhan ekonomi. Komite ini berfungsi sebagai unit koordinasi, bertanggung jawab untuk membuat keputusan untuk mengatasi ketidakefektifan koordinasi diantara berbagai pemangku kepentingan dan untuk mengatasi berbagai hambatan proyek infrastruktur strategis nasional (KPPIP, t.t.).

Indonesia juga memahami posisi dan tanggung jawab vitalnya untuk mewakili negara-negara berkembang. Pertama, Indonesia 
merupakan salah satu negara berkembang yang karena pertumbuhan ekonominya tercatat cukup penting di antara negaranegara berkembang lainnya dimasukkan dalam kategori emerging economy; sebagai emerging economy Indonesia mendapat hak istimewa untuk duduk dalam klub tersebut. Kedua, Indonesia merupakan negara dengan jumlah penduduk terbesar keempat setelah China, Amerika Serikat, dan India. Ketiga, mayoritas penduduk Indonesia beragama Islam dan karenanya dapat memainkan peran potensial untuk menjembatani perbedaan-perbedaan di antara peradaban dunia. Keanggotaan Indonesia dalam klub dapat membantu memperbaiki citra tentang perbedaan antara Barat dan Islam. Keempat, Indonesia merupakan negara demokrasi baru yang dalam proses konsolidasi. Keanggotaan Indonesia dapat memberikan inspirasi ke negara-negara lain untuk mempromosikan demokrasi dan mempertahankan perumbuhan ekonomi tinggi. Kelima, secara geografis Indonesia memiliki posisi yang signifikan sebagai satusatunya anggota ASEAN yang menjadi anggota tetap G-20. Tentu saja bisa ditambahkan bahwa Indonesia adalah salah satu negara berkembang yang di masa lalu pernah terpuruk oleh krisis ekonomi yang dahsyat dan kini telah berhasil mengatasinya dengan relatif baik. Selain potensinya sebagai global buyer yang besar di dunia karena jumlah penduduknya yang besar, pertumbuhan ekonomi Indonesia yang stabil akan berdampak secara sistemik kepada stabilitas pertumbuhan ekonomi negara-negara di kawasan Asia Tenggara, dan lebih lanjut memberikan kontribusi stabilitas perekonomian di Asia dan dunia.

Selain itu, peran Indonesia sebagai negara dengan mayoritas Muslim memberikan citra positif bagi G-20, terutama untuk menangkis persepsi negatif dari tesis clash of civilization antara peradaban Barat dan Islam. G-20 merupakan anti-tesis perbenturan peradaban yang menunjukkan bahwa Barat siap bekerjasama dengan negara-negara Muslim. Di dalam KTT G-20 di Hamburg, Jerman, Presiden Jokowi menjadi salah satu Lead Speaker pada sesi Retreat yang mengangkat tema "Fighting Terrorism". Pada kesempatan ini, terdapat empat hal pokok yang disampaikan. Pertama, G-20 perlu memperhatikan eskalasi serangan dan regionalisasi terror ISIS. Kedua, Indonesia menggunakan keseimbangan pendekatan hard power dan soft power guna mengatasi terorisme, termasuk melalui pemberdayaan organisasi keagamaan seperti NU. Ketiga, dorongan agar G-20 berupaya menyelesaikan akar permasalah terorisme dengan 
mengatasi ketimpangan kesejahteraan dan mewujudkan ekonomi inklusif. Keempat, apresiasi terhadap dukungan G-20 untuk keanggotaan Indonesia dalam Financial Action Task Force (FATF).

Sebagai anggota G-20, Indonesia memiliki peluang lebih baik daripada negara-negara berkembang non-anggota dalam memecahkan masalah ekonomi dan keuangan global. PDB yang relatif lebih besar dan ukuran yang besar dalam populasi dibandingkan dengan anggota ASEAN lainnya bisa menjadi alasan utama masuknya Indonesia sebagai anggota G-20. Meskipun memiliki jumlah anggota yang lebih banyak daripada G8, G-20 masih dianggap menarik sebagai suatu forum dengan keanggotaan eksklusif, meskipun pertanggungjawaban legitimasinya bukan dari bukan anggota.

\section{Tantangan bagi Indonesia dalam Keanggotannya di G-20}

Indonesia sebagai negara berkembang tentu mengalami tantangantantangan sebagai anggota G-20. Tantangan dalam membangun ekonomi Indonesia secara internal adalah struktur ekonomi Indonesia, sedangkan tantangan eksternal bagi Indonesia adalah terjadinya perlambatan pertumbuhan ekonomi dunia. Presiden Jokowi juga harus bisa membawa kepentingan-kepentingan ekonomi domestik ke dalam agenda G-20. Indonesia, yang memiliki struktur perekonomian di bidang agraris, harus berupaya melakukan peningkatan ketahanan pangan dan sistem pangan yang berkelanjutan.

Identifikasi tantangan yang dihadapi oleh indonesia baik tantangan eksternaldantantanganinternal. Dilevel internal, terdapatsetidaknya dua tantangan utama yang harus dihadapi oleh Indonesia dalam rangka peningkatan perannya di G-20. Pertama, struktur ekonomi Indonesia harus sejalan dan disesuaikan dengan kesepakatan kerja G-20. Selain itu, Indonesia harus mampu membentuk agenda G-20 agar sejalan dengan kepentingan nasional. Sedangkan tantangan kedua berbicara banyak mengenai kepastian hukum, termasuk regulasi-regulasi peraturan dan hukum yang berlaku. Proses politik dalam pemenuhan komitmen yang akan dibawa oleh Indonesia. Selanjutnya di level eksternal, terdapat lima alasan yang dapat diidentifikasi oleh penulis jika dikorelasikan terhadap penguatan 
posisi Indonesia di forum G-20. Tantangan eksternal pertama berkaitan dengan perlambatan pertumbuhan ekonomi dunia, sedangkan proses perkembangan G-20 yang sangat cepat membuat negara-negara anggota diharuskan mampu mengikuti arus, serta dinamika proses tersebut. Tantangan tersebut berkaitan dengan tantangan eksternal kedua yakni adanya instabilitas kondisi finansial di level global. Tantangan eksternal ketiga berasal dari tingginya resiko terhadap pengaruh internasional semakin meningkatnya interdependensi dan vulnerability atau celah keamanan. Tantangan keempat terkait dengan tanggung jawab Indonesia untuk turut serta dalam meningkatkan pertumbuhan ekonomi global dan mengatasi krisis. Hal ini bisa dilakukan Indonesia dengan meningkatkan produktivitasnya dan berperan aktif dalam membangun ekonomi global yang sejalan dengan pembangunan ekonomi nasionalnya. Sedangkan tantangan eksternal terakhir datang dari level regional yakni sebagai negara anggota ASEAN satu-satunya di G-20, Indonesia mempunyai tanggung jawab untuk membawa kepentingan-kepentingan ekonomi ASEAN ke dalam G-20.

\section{Simpulan}

Dalam forum G-20 negara Indonesia berperan aktif serta ikut berkontribusi sebagai anggota tunggal yang berasal dari kawasan Asia Tenggara, di dalam forum ini Indonesia banyak menghadapi tantangan seperti bagaimana Indonesia harus dapat menjaga kestabilan negara khususnya dalam kebijakan ekonomi. Selain itu, Indonesia harus jeli dalam melihat dan belajar bagaimana kerja sama yang dijalin dengan negara-negara lain, khususnya dengan negara maju, dapat menguntungkan kedua belah pihak dan tidak saling merugikan. Selain itu, Indonesia harus mampu mempersiapkan diri dan mampu bersaing dalam dunia perekonomian agar tidak tertinggal dengan negara anggota lainnya dan sebagai satu-satunya negara yang mewakili ASEAN, Indonesia memiliki tanggung jawab yang besar. Indonesia tak hanya harus membawa kepentingan domestik dalam negeri, namun juga membawa kepentingan ASEAN ke dalam forum ini. Namun dalam forum G-20, ini Indonesia memiliki beberapa peluang besar. Jika Indonesia dapat memanfaatkan peluang tersebut, maka Indonesia kemungkinan mendapatkan keuntungan maksimal. Peluang-peluang yang tersedia dalam G-20 bagi Indonesia, antara lain: 1) meningkatkan 
investasi dan strategi investasi; dan 2) peningkatan pembangunan nasional, seperti pembangunan infrastruktur, keuangan inklusif, mobilisasi sumber daya domestik, ketahanan pangan dan gizi, pengembangan sumber daya manusia, dan bisnis inklusif.

Indonesia dapat meningkatkan sektor investasi dan perdagangannya dengan cara meningkatkan nilai ekspor melalui kerja sama yang dapat dilakukan di dalam G-20, mendorong kontribusi investasi dan perdagangan dalam pertumbuhan global, memanfaatkan jaringan global dan melakukan evaluasi terhadap pelaksanaan perdagangan bebas, dan melakukan penguatan terhadap sistem perdagangan multilateral. 


\section{Daftar Pustaka}

\section{Buku}

Ikbar, Yanuar. 2007. Ekonomi Politik Internasional 2. Bandung: PT. Refik Aditama.

Baylis, John. 2014. The Globalization of World Politics: An Introduction to International Relations. Oxford: Oxford University Press.

Hara, Abubakar Eby. 2011. Pengantar Analisis Politik Luar Negeri Dari Realisme sampai Konstruktivisme. Bandung: Nuansa.

Kementrian Perencanaan Pembangunan Nasional. 2014. Rencana Pembangunan Jangka Menengah Nasional 2015-2019. Jakarta: Kementerian Perencanaan Pembangunan Nasional.

OECD. 2016. Survei Ekonomi OECD Indonesia. Paris: OECD.

\section{Internet}

Connelly, Aaron L. 2014. Indonesian Foreign Policy Under President Jokowi [online]. https://www.lowyinstitute.org/ publications/indonesian- foreign- policy-underpresident-jokowi [Diakses pada 18 Oktober 2017].

Deutsche Welle. 2017. Inilah Visi Jokowi di KTT G-20 [online]. http://www.dw.com/id/inilah-visi-jokowi-di-kttG-20/a-39611456 [Diakses pada 21 Oktober 2017].

Kirton, John. 1999. What is G-20? [online]. http://www.G-20. utoronto.ca/G- 20whatisit.html [Diakses pada 21 Oktober 2017].

KPPIP. tt. Progress Of Infrastructure Development In Indonesia [online]. https://kppip.go.id/en/about-kppip/progress-ofinfrastructure- development-in-indonesia/ [Diakses pada 21 Oktober 2017].

www.presidenri.go.id. 2016. Visi Nawacita dalam Politik Luar Negeri Indonesia [online]. http://www.presidenri.go.id/programprioritas-2/visi- nawacita- dalam-politik-luar-negeriindonesia.html [Diakses pada 21 Oktober 2017]. 